\title{
医薬分業における調剤薬局の戦略的行動の経済分析
}

\author{
櫻井秀彦
}

\section{Economic Analysis of Strategic Behavior in Dispensing Pharmacies in the Separation of Dispensing and Prescribing Functions}

\author{
Hidehiko SAKURAI \\ Hokkaido College of Pharmacy, 7-1 Katsuraoka-cho, Otaru, Hokkaido 047-0264, Japan
}

(Received October 16, 2002; Accepted January 6, 2003; published online January 8, 2003)

\begin{abstract}
In recent years, the system for the separation of dispensing and prescribing functions (SDP) has progressed in Japan. However, because of the failure of the healthcare system, it is difficult to estimate how the system of SDP contributes to the improvement of patient utility and welfare. In this paper, I try to evaluate the SDP by analyzing the strategic behavior of dispensing pharmacies, employing some economic models under imperfect information. In these models, quality is characterized as a strategic variable in monopolistic or duopolistic competition. As a result, I show that competition among dispensing pharmacies in the SDP raises the quality of pharmaceutical services, but there is some possibility of "excess entry" with free entry.
\end{abstract}

Key words — - strategic behavior; dispensing pharmacy; separation of dispensing and prescribing functions

\section{1. はじめに}

日本薬剂師会の調査によれば，平成 13 年度の処 方箋受取率は $44.5 \%$ となり，わが国の医薬分業 は，着実に浸透してきていると言える。しかし，医 薬分業に関して国民的なコンセンサスが得られた上 での制度設計がなされた訳ではなく，場当たり的な 政策が先行し, 各経済主体がその都度対応するとい う状況にある.

実際，わが国の医薬分業が進展するきっかけとな つたのは, 薬価差益の縮小による, 出し手側である 病院等の経営事情と, それに呼応する形での, 受け 手側である調剤薬局チェーンや商社の拡大戦略行動 であると言っても過言ではない。すなわち, 現在の わが国の医薬分業制度は, 本来医療保障制度の中心 となるべき患者と, 医療機関との相互関係によって もたらされたものではなく, また社会的な合意の上 での新たな制度設計によるものでもない。いわゆる 点分業のマンツーマン又は門前が主体であり, 理想 とは異なった分業形態が先行しているのも, このこ とを物語つている.

そこで，本稿では，わが国における医薬分業につ

北海道薬科大学

e-mail: hsakurai@hokuyakudai.ac.jp
いて，次の 3 つの問題意識で経済モデルによる分析 を行った．まず，第 1 に現行制度下での医薬分業は 本当に患者のためになるのか, 若しくは患者の効用 （満足度）を高めるのかを, 主に調剤サービスの品 質に着目して検討する，第 2 に，患者だけでなく， 社会全体で見た場合には, 医薬分業が浸透すること は厚生水準を高めることになるのかを検討する．第 3 に調剤薬局では直接的に医療保障における給付行 為に携わりながら, 営利の追求, 利潤の分配が認め られているが，このことでの弊害はないのかを検討 する.

調剂サービス市場は，公的な価格規制の存在や医 療保険の完備など，一般の財・サービスの市場とは 極めて異なつた構造を持つ市場であり, 通常の経済 分析に用いる仮定を採用できない。 そのため, 通常 の経済分析モデルを大きく変更するか, 極めて特殊 なモデルを構築して分析に用いるなど, 事前の準備 が必要となる。さらに, 医薬分業に限れば, 欧米で は何世紀も前に確立された制度であり, 医療給付制 度の基本又は常識となっているためであろうか, 医 薬分業を直接的に経済分析の対象として取上げた先 行研究は, 筆者の知る限り見当たらない. また, わ が国においては，国保デー夕を用いた実証分析で, 
泉田・山田 ${ }^{1)}$ があるが，これは病院側が院外処方と する意思決定に与える諸要因を分析したものであ り，医薬分業の経済的な帰結や患者に与える効果を 直接的に分析したものではない.

本稿では, 以下，分析の前提となる理論をサーベ イした上で, 適切と考えられるモデルを構築し，そ こから得られた帰結について検討を加えることとす る.

\section{2. 理論モデルにおける前提条件の検討}

ここでは，一般の経済理論モデルでは前提とされ ていない, 又は捨象されてしまうような, 医薬分業 における制度的制約や市場環境を，これから分析に 用いる理論モデルに反映させ，これにより適切なモ デル構築の準備を行う。まず，薬剤師から患者に提 供される調剤サービスの属性についての理論的な検 討を行い，続いてそれが取引される患者と薬局間の 需要と供給における特性や環境についての検討を行 う.

2-1. 調剤サービスの検討 まず，調剤の財・ サービスとしての属性を考える。経済学では一般に 取引される財の情報について，消費者は既に完全に その情報を把握していると言う “完全情報”を前提 とする．しかし，現実を考えれば，財の情報を探す ときにコストがかかる探索財 (search goods), 2) 購 入後使用してみないとその価值が判らない経験財 (experience goods),3) 何か事が起こってからでない と価値が判らない信任財 (credence goods),4)など に分類でき，一般に調剤サービスはこれらすべての 属性を備えていると考えられる。 すなわち, 医薬分 業における薬剤師の薬暦管理や服薬指導も, 実際に 薬局を選択した後でなければ，どのような品質の サービスが提供されるのか不明であり, 経験財とし ての属性を備えていると言える. また, 重複投薬や 相互作用を有する薬剤が見つかるなどしなければ, 本来のサービスの価值が判らず，信任財としての属 性も備えていると言える。患者の医師の選択に関し ての情報収集行動は, サーチ（search）モデルや評 判（reputation）モデルとして，医療経済学でも一 般的なものとして広く分析に援用されているが, 調 剤薬局の選択に関しては, 現在の点分業が主体であ る状況を考えれば，患者は薬局の情報収集にそれほ どコストかけているとは考えられず，この属性につ いては本稿の分析モデルには反映しないこととする.
2-2. 調剂市場の検討 また，制度的な制約条 件を考えても，わが国の調剤市場では公的価格規制 が前提であり, 競争市場で勝ち残るための企業の考 える戦略変数としては，「サービスの一部の保険請 求を行わないなどの例外を除けば」, 価格ではな く, 数量や質といつたものが用いられる. 当然, 政 策評価のために，院外処方に移行する事前と事後 の, 薬及びその他調剤サービスの数量の変化には注 目しておかなければならない。しかし，院外処方が 決定してしまえば，処方箋発行によって供給量が一 意に決められるので, やはり戦略変数は質と言うこ とになる。このため, Riordan ${ }^{3)}$ の経験財の独占競 争に関する先行研究が, 調剂薬局の戦略的行動を通 じての医薬分業の分析に応用できると考えられる. これは古典的な Hotelling ${ }^{5)}$ の線分モデルから Salop ${ }^{6)}$ の円環モデルへと拡張された, 空間的競争 モデルを援用したモデルである．空間的競争モデル は, 距離が独占的, 又は寡占的な企業の価格戦略 や，そのモデルにおいて自由参入を想定した場合に 参入する企業の数に与える影響を分析した。 ここ で, この距離という変数を, 物理的な距離としてだ けでなく，消費者がその企業へアクセスするための 総費用と考えると, 患者と調剤薬局の相互関係の分 析に援用できそうである. 実際, 病院・診療所から 処方箋を渡されて, 調剤薬局を選択する場合には, どこから近いのか（病院, 自宅, 職場, 又はよく利 用する商店や銀行からの距離）とその時点での利用 のしやすさ（交通機関, 駐車場) など様々な要因が 影響すると思われる.

\section{3. モデル}

3-1. 基本モデル ここから, 理論モデルによ る分析を行う。まず，患者の選好Uは次のよう な，満足度を示す効用関数で表されるとする。

$$
\mathrm{U}=h(q)-t z-p
$$

$q$ は薬局から患者へ提供されるサービスの品質を, $z$ は患者と薬局の距離を, $p$ は調剤サービスの価格 を表す。 $t$ は非負のパラメータで, $h(\cdot)$ は提供さ れた任意の品質によって患者が受ける効用水準であ り $, h^{\prime}>0, h^{\prime \prime}<0$ と言う下から凹な形状を仮定する. $q$ は $0 \leqq q \leqq \infty の$ 值をとり,$q=0$ は薬局が選択でき る最低の品質である。 $z$ は先にも触れたとおり, 患 者と薬局との距離を代表する変数であるが, 現実に 照らせば，アクセスに要するすべてのコスト, 若し 
くは困難さや障害の度合いを意味する変数と考える こととする.

さらに，この患者は 1 度のみでなく, $k$ 回にわた って調剤サービスを受けるものとする，ただし，毎 回同じ薬局を選択するとは限らない。すなわち，あ る薬局が患者の予想より劣る，品質の低いサービス を提供した場合には，次回はその薬局は選択されな い可能性があると言うことである。

薬局の行動については, まず次のような費用関数 を仮定する。

$$
C=q \mathrm{x}+F
$$

$\mathrm{x}$ は処方枚数（顧客数）若しくは提供されるサービ スの量であり，Fは固定費用である，そして，薬局 は利潤

$$
\Pi=p \mathrm{x}-q \mathrm{x}-F
$$

を最大化しようとして行動するとする，ここで，先 に述べたように各患者との $k$ 回の取引を盛り込ん だことにより，薬局は超短期的に利潤の最大化を狙 えば $q=0$ となるが，品質がその患者のその後の取 引に与える影響や，評判といつた正の外部効果に与 える影響を考えれば，利潤最大化という行動原理の 下でも，企業が最低の品質を選ぶ可能性は少なく， むしろ患者の効用関数の $h(\cdot)$ に影響を与えよう と品質を可能な限り高めるインセンティヴを持つこ とが言える.

次に市場の構造であるが，この市場は仮想的に円 環状になっており，参入している薬局数は $n$ で, 薬局は対称的に一定の間隔でこの円周上に位置して いるものとする (Fig. 1)。ささらに，この市場に患 者は密度 $M$ で一様に分布しているものとする．円

\section{Pharmacy,No. $n$}

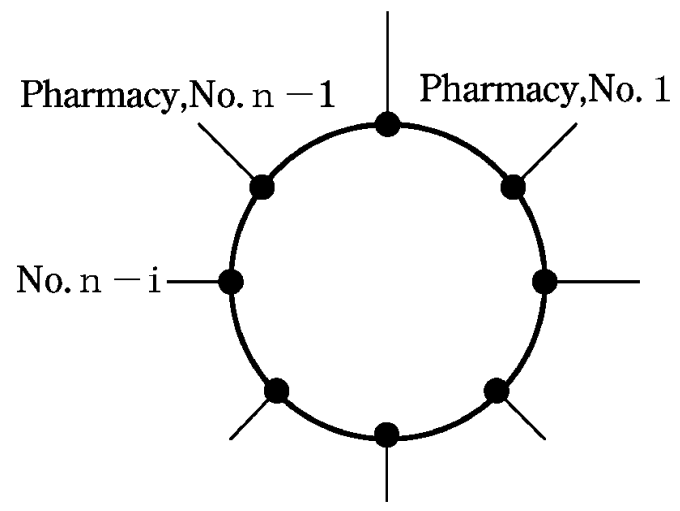

Fig. 1. The Model of the Circular City
周は便宜的に長さが 1 であるとする.

以上のようなモデルを用いて，以下，完全情報と 不完全情報の諸ケースで帰結がどのように変わって くるかを見てみることとする

3-2. 完全情報の下での行動 ここでは, 患者 が薬局の提供するサービスの品質を，事前に観察可 能であるとして議論を進める. 患者は, 現在この市 場に存在している $n$ 社の薬局のうちから，自身の 効用を最大にしてくれる 1 社を選ぶことになる.

仮に選択される薬局の価格を $p$, 品質を $q$ とし て, 他の比較される薬局については, 一様に価格 $p^{\mathrm{c}}$, 品質を $q^{\mathrm{c}}$ であるとする。ここで, 品質に加 え, 価格の違いをも想定したのは, 当然にこれから の議論に有用であるためであるが，実際に集中度の 違いによる調剤報酬の差別化が行われていることか ら，極端に現実から乘離した仮定ではないと思われ る。すると，患者の効用が無差別（等価）となる位 置を考えると, 比較される薬局の距離は円周 1 を $n$ で除したものから $z$ を引いたものであるので,

$$
h(q)-t z-p=h\left(q^{\mathfrak{c}}\right)-t(1 / n-z)-p^{\mathfrak{c}}
$$

が言える。これを整理して,

$$
z=\left[h(q)-p-\left(h\left(q^{\mathfrak{c}}\right)-p^{\mathrm{c}}\right)\right] / 2 t+1 /(2 n)
$$

が求まる。また，すべて価格が同じであれば，

$$
z=\left[h(q)-h\left(q^{\mathrm{c}}\right)\right] / 2 t+1 /(2 n)
$$

となる，そして， 円周上に位置していることを想定 しているため, 左右両側に分布する患者との距離は $2 \mathrm{z}$ となり, 各患者 $k$ 回の来局を仮定しているの で，この薬局の直面する需要 $D$ は,

$$
D=2 z M k
$$

となる.

さらに，このような完全情報の下での品質と価格 が，どのように均衡しているかを確認してみよう。 まず，この場合に，円周上の各位置にいる薬局は， 各々の周辺に分布する患者に対しては独占的な行動 が取れることを確認しておこう。なぜならば，患者 がそれを嫌ってより遠方の薬局を選択することは, より高いコスト（z）がかかるからである。そのた め, (6) 式から, この薬局の利潤最大化問題は,

$$
\Pi=(p-q) \cdot 2 z M k-F
$$

の一階の条件をゼロとおいて解き，さらに，対称性 の条件となる $p=p^{\mathrm{c}}$ を用い, この場合での均衡価格 を $p^{*}$ とし，社会的に最適な品質を $q^{0}$ とすれば，

$$
p^{*}=q^{\mathrm{o}}+t / n
$$


と表せ, 自由参入を前提とすれば，正の利潤が出て いるかぎり，新規の参入は止まないことになる.

そこで, 均衡参入薬局数を求めて見ると,

$$
N^{*}=(k M t / F)^{1 / 2}
$$

となる. ただし, 企業数であるにも関わらず, 整数 にならない場合もありうるが，ここでは後に大小関 係が把握できれば目的は達成されるので, 無視する こととする。

次に, 社会的に見て望ましい水準を求めて見る. 薬局数 $n$, 価格 $p$ を所与とする, ここでの社会全体 の厚生 $W$ は,

$$
W=2 k n M \int_{0}^{1 /(2 n)}[h(q)-t z-p] \mathrm{dz}-n F
$$

のように，すべての患者の効用を積分したものか ら，社会全体の費用を除いたものとして表せる。こ の社会的厚生水準を最大にする最適な企業数 $n^{\circ}$ は, (10) 式の最大化の条件

$$
d W / d n=0
$$

より,

$$
n^{\mathrm{o}}=(k M t / 4 F)^{1 / 2}
$$

となる

ここで，(9)式と(12) 式を比較して見ると，過剰 参入 (excess entry) が生じており, 社会的に見て 望ましい水準の 2 倍の数の薬局が市場に参入してい ることが判る.

\section{3-3. 不完全情報の下での行動 I ：経験財のケー} ス 次に不完全情報の下での分析を行う。ここで は，まず薬局から提供される調剤サービスが，経験 財の属性を備えているとして, 患者と薬局の行動が どのように変化するかを見てみることとする，すな わち, 患者は薬局の調剤サービスの品質のみ, 事前 に知ることができないとして議論を進める.

経済学では，売り手と買い手の間で，持っている 情報量に差があることを情報の非対称性と呼ぶが, 経験財もそのケースに含まれる。この情報の非対称 性が存在する時に, 価格は品質などのシグナルとし て利用される. 特に, 本稿では繰返し購入 (repeat purchase）が仮定されており，このシグナルの役割 は大きい. しかし, 調剤市場の場合は, 価格規制に より，価格をシグナルとして利用することはできな い. ここでも Riordan の分析 ${ }^{3)}$ と対比させる形で議 論していく.

まず，ここでは当該薬局は価格 $p$ を選択し，他
社は価格 $p^{\mathrm{c}}$, 品質 $q^{\mathrm{c}}$ を選択するとする. 薬局と患 者の間の距離に関して, 次も同じ薬局へ行くという 選択は，

$$
z=\min \left(y, z\left(q ; U^{c}\right)\right)
$$

という $z$ の距離内にいる患者が行う. 最初は, そ の薬局を選択するものとすると, 距離に関するコス

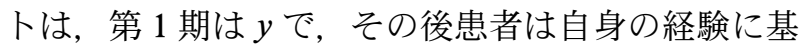
づいて $(k-1)$ 回薬局の選択を繰り返す，そのた め, 当該薬局の利潤最大化は,

$\Pi=2 M(p-q)\left\lceil y+(k-1) \min \left(y, z\left(q ; U^{c}\right)\right)\right]-F$

で示され，この薬局はそのための最適な水準の品質 を選択することとなる。しかし，患者の選択行動 は, 費用の最小化も目標となり, 当該薬局が品質を 高めようとしても，価格はシグナルとして使えず, 財の属性上患者は観察不可能なので, 行動に影響を 与えられないため, 単に費用増になるのみである. よって (13) 式においては常に $z\left(q ; U_{\mathrm{c}}\right)$ が選ばれ,

$$
\begin{aligned}
\max \Pi= & 2 M(p-q)\left\lceil y+(k-1) \cdot z\left(q ; U^{\mathrm{c}}\right)\right]-F \\
& \text { s.t. } y-z\left(q ; U^{\mathrm{c}}\right)>0
\end{aligned}
$$

の最大化問題を解くことで, 均衡品質が求まる.

次に, 最初に患者が当該薬局へ行くとした仮定を 緩め, 品質によって繰返し薬局へ行くような条件を 考えると

$(k-1)\left\{[(p-q) / 2 t] h^{\prime}(q)-z\left(p, q ; U^{c}\right)\right\} \geqq y$

が言え，かつ

$$
y=z\left(p, q ; U^{c}\right)
$$

と無差別でなくてはならない。 そして，これらは実 は端点解であり，これは当該薬局が(17)式の条件を 満たす最適な品質を選択し, かつその品質 $q$ が (16) 式の条件を満たすときのみ, 距離 $y$ 内にいる患 者すべてが最初にその薬局へ行くことを意味してい る. (5) 式を(4) 式へ代入し, 整理すると, $(k-1)[(p-q) / 2 t] h^{\prime}(q)-k \cdot z\left(p, q ; U^{\mathrm{c}}\right) \geqq 0$

が得られる.これは, 患者は価格をシグナルとして 利用し，（18）式の条件を満たすような品質を期待 し, 薬局も品質に関してそのようなインセンティヴ を持つということである。 しかし，先ほどから触れ ている通り, 調剤市場では, 価格設定は政府側が行 い，独占的な供給者も価格設定はできない。このよ うな場合は，規制価格を $\bar{p}$ とし， 
$(k-1)[(\bar{p}-q) / 2 t] h^{\prime}(q)-k \cdot z\left(\bar{p}, q ; U^{\mathrm{c}}\right) \geqq 0$

を検討することとなる，この式の左辺は，仮定より 厳密に $q$ の減少関数であり, この条件の中で品質 を最大化しょうとした場合を考えると, 不等式を等 式に見たてて変形し,

$$
\bar{p}=q+\left\{k\left(h(q)-q-U^{\mathrm{c}}\right) /(k-1) h^{\prime}(q)+1\right\}
$$

と整理できる.この式は, 右辺が品質 $q$ について の増加関数になっており, ここでの仮定の下では価 格規制の弊害が見られることを示している．また， 逆に品質を左辺にとつて整理すると, 価格の調整が 可能であれば，増加関数であり，「例えばジェネリ ックでの代替調剤など，価格の選択の可能性を導入 するのであれば,」価格の上昇は高い期待品質を導 くと言え, やはり経験財市場ではシグナルとして機 能していることが判る.

3-4. 不完全情報の下での行動 II：信任財のケー ス では, 同じく不完全情報下であって, さらに 薬局から提供される調剤サービスが，信任財のケー スであったとしよう。この場合，実際に重複投薬や 併用禁忌な処方が見つかるか, 又はそれらが見過ご され，患者に問題が発生するなどしなければ，薬剤 師が提供しているサービスの本来の価值若しくは品 質が患者には把握できないとしょう。ここでは, 従 前の経験財のケースと異なり, 品質が最後まで観察 できないので, 需要側である患者の行動に影響を与 えるものは, 距離のコストしかない.すなわち, よ り単純な空間的円環競争モデルによる分析結果と同 じ帰結が得られることとなる. Salop $\left.{ }^{6}\right)$ から結論の み引用すると, やはり過剰参入定理が支持され, 当 該企業にとっては，厳しい競争環境が持続するもの の, バラエティの増加という点で患者の便益に貢献 すると言える.

ただし，当然ながら品質に関する分析は必要であ り，そのためには，不確実性を導入するなどした， 別なモデルによる分析を行わなければならないが, 他のケースとの整合性がとれなくなってしまう。

3-5. 非営利の原則と利潤最大化行動 最後 に, 医薬分業は外来の投薬部門における外部委託と 受け止めることができ, ここで, 薬及び調剤サービ スの提供主体が病院から調剂薬局へ変化することに よる経済的な含意を検討する.
経済学では，供給側の企業の行動原理は，一般的 に利潤の最大化と仮定し，分析される．しかし，病 院・診療所の行動原理は, 非営利性の原則により, 利潤最大化とすることはできない。わが国における 非営利性とは, 事後的に利益が出ることは認める が，事前に営利を追求することは認めないことを言 う. 具体的には, 現段階では株式会社の病院経営の 参入が認められていないなど, 配当などを通じて余 剰金を利益として外部へ分配することを目的に活動 できない.

このようなことから, 医療経済学では病院の行動 原理として, 目標所得仮説 (target income hypothesis）が有力となっている. 目標所得仮説とは, 医 療機関又は医師は一定の利潤を留保した上で, 医療 サービスの品質を最大限に高めるとする仮定であ る。利潤を $\pi$, 一定の収入を $R$ とすれば，効用関 数は,

$$
V=\alpha(\pi-R)+\beta q
$$

と表せる.ここで， $\alpha$ と $\beta$ はともに非負のパラメー 夕で, $\alpha$ と $\beta$ の大小関係で, 収入と品質のどちらに 効用のウェイトがかかっているかも想定できる.こ の効用関数を目的関数にすれば，入院における医療 サービスの分析などが可能となる。ささらに，利潤に ついてゼロと最大という両極端のケースを想定し た，以下の 2 つのモデルが提唱されている. 留保す る利潤をゼロとする非営利企業モデルは, 医療サー ビスの量と質を説明変数とし, 病院の管理者の効用 を被説明変数とする効用最大化モデルであり, 逆に 留保する利潤を最大化する非営利企業モデルは, 医 師の所得, 厳密には医師の平均所得 NARP (net average revenue to physicians) を最大化するという 所得最大化モデルである.

では, 調剤薬局の場合はどうであろうか。本稿の モデルでは，利潤最大化を仮定したが，現実に，多 くは民間の営利企業による経営であり, 利潤最大化 の行動基準はそのまま当てはまると考えられる，た だし, 薬局及び薬局チェーンの多くは, 薬剤師によ る経営であり, 行動原理の $100 \%$ が利潤追求とも考 えにくい，先に述べたような，医療の品質にも関心 を図っている企業がほとんごであると考えられる. 本稿では, 分析のいつそうの複雑さを避けるため, 単純な行動モデルとしたが，現実を反映すれば，ま た違つた帰結が得られた可能性がある。 


\section{4. 分析結果}

以上，本稿では，現状での医薬分業が社会に与え るメリット，デメリットを経済モデルによる分析で 行ってきた。医薬分業が大きく進展し, 調剤薬局に よる医薬品の提供が一般的な形態となったときに, 以上の分析からは,

(1)患者に提供されるサービスの品質は向上する,

(2)参入する薬局数は, 社会的に望ましい水準より 過大となる傾向がある,

(3)病院・診療所と異なり, 利潤を追求する企業が 直接医療給付サービスを行うことでの弊害は，ほと んどないと考えられる，という帰結が得られた。

第 1 の薬局の競争による品質の向上は, 望ましい 姿であり, 第 2 の, 過剩参入が起きうる可能性を示 唆することについては, むしろバラエティの増加に よる，新しい医療サービスが患者に提供されること となり，望ましいと考える，ただし，社会全体での 固定費用 $(\Sigma F)$ の増加は, 資源の希少性の観点か らは問題を残す。これには，新たな参入規制などの 措置が考えうるが, 筆者は賛成しない。医療制度は 患者が中心となるべきであり，医療サービスが量的 に過剩に供給されたり, 資源が不必要に消耗された りしなければ，患者の便益を価值判断基準の第 1 に するべきと考える.

また, 第 3 の営利追求行動は, 結果的に品質の向 上や, バラエティの増加といった, 患者の厚生を高 めており，弊害はないと考える.

\section{5. 結語}

調剂も含む医療サービスと一般の財・サービスと の違いは, 社会保障給付の名の下にほとんどが価格 規制下に置かれていると言うことである。この理由 は，情報の非対称性の存在が不可避であり, 患者が 正しい価值判断ができないため, 代わりに別の機関 が価格設定すると言うものである。免許制度も，一 定水準以上の質のサービスが提供されることをシグ ナルとして発信することを公的に認め, 患者が取引 に消極的になることを排除しようとしたものである.

医薬分業の評価にはもちろん，賛否両論があり， 例えば，大病院の外来で受診した場合などでは, 薬 が処方されるまでの待ち時間が削減され, 病院薬剤 師も入院患者に専念できるなど, 患者の便益に寄与 する面も見られるが，これはそもそも病院の機能分 化が制度的に行われてこなかったことによるもの
で，受診までの待ち時間も無駄なものとなってお り, 医療サービスの効率化のための抜本的な解決策 となっているとは言えない. また, 集中度の違いに より, 調剂報酬を差別化するなど, 面分業の普及政 策が取られているが, この差別化は, 患者に提供さ れるサービスの違いによるものでもなく，また，そ の報酬の違いが店頭において患者に明示されている 訳でもない。

また，ここしばらくは医薬分業が根付く過渡期で あり，時間の経過に伴い，自然と理想的な体制にな るとの意見もある。しかし, 現在わが国は医療保険 制度の危機に直面し，国民医療費の適正化という重 要課題に取組むことが急務であり, 高度情報化社会 の到来と言われている現代において, また, 欧米諸 国と言う先行モデルがあるにもかかわらず，理想と される形態が普及しない現状を放置しておくことは 問題であろう.

経済学では，ある一定の条件が満たされれば，市 場メカニズムが理想的な資源配分を実現するとい う，アダム・スミス以来の共通認識がある。いわゆ る「神の見えざる手」というものである. しかし， 医療の世界にあっては，前提となる条件が満たされ ないため，市場原理に委ねることはできず，どうし ても政府の介入が必要となる。 それゆえ, 医療制度 設計は, 政府の重要な役割と言え, 直接影響を受け る国民はその政策に対し，常に監視の目を持ち続け なければならない。

最後に, 本稿の研究の今後の課題としては, 各診 療報酬体系をも盛り込んだ，より現実に沿つたモデ ルの構築や，いわゆる面分業や点分業といつた分業 形態の違いによる分析, 及びデータの制約は予想さ れるが，実証分析による確認が必要であり，取り組 んでいきたいと考えている.

\section{REFERENCES}

1) Izumida N., Yamada T., Byouinkanri, 37, 3388 (2000).

2) Nelson P., J.P.E., 78, 311-329 (1970).

3) Riordan M. H., Q.J.E., 101, 265-279 (1986).

4) Darby M. R., Karni E., J.L.E., 16, 67-88 (1973).

5) Hotelling H., Econ. J., 39, 41-57 (1929).

6) Salop S. C., Bell Journal of Economics, 10, 141-156 (1979). 